\title{
XVIII
}

\section{Afghanistan Legal Lessons Learned: Army Rule of Law Operations}

\author{
Eric Talbot Jensen and Amy M. Pomeroy*
}

$\mathbf{I}$

n 2002, the White House published the National Security Strategy. Rather than

focusing exclusively on military operations, the strategy is comprehensive and recognizes that acts ranging from poverty reduction to disease eradication will contribute to America's national security. However, one of the most crucial components of the National Security Strategy which will impact virtually all other components is the worldwide implementation of the rule of law. ${ }^{1}$ In furtherance of the National Security Strategy, National Security Presidential Directive 44 was issued in late 2005 and states that it is US policy to work with other countries toward effective implementation of the rule of law. ${ }^{2}$ The directive tasks the Secretaries of State and Defense with coordinating rule of law efforts and with integrating them into military contingency plans. Consequently, by direction of the President, the military has a key role to play in implementing the rule of law and judge advocates (JAs) must be prepared to lead these efforts.

* Lieutenant Colonel Eric Talbot Jensen, Judge Advocate, US Army, and Amy M. Pomeroy, Student, Brigham Young University Law School serving as a Legal Intern, International Law Branch, Office of The Judge Advocate General, US Army. The views expressed in this article are those of the authors and not The Judge Advocate General's Corps, the United States Army or the Department of Defense. 


\section{Afghanistan Legal Lessons Learned: Army Rule of Law Operations}

Commanders look to JAs with the expectation that they will be competent and innovative in implementing the unit's rule of law mission. ${ }^{3}$ This is clearly demonstrated by the Center for Law and Military Operations' publication of the Rule of Law Handbook: A Practitioner's Guide for Judge Advocates (Rule of Law Handbook), where a "constantly re-occurring theme" is that "the command naturally turns to the legal expert within the task force to plan, execute, coordinate, and evaluate rule of law efforts." 4

Over six years of operations in Afghanistan, during which commanders have relied on JAs in their rule of law operations, have created a number of lessons learned; this paper will highlight three:

- Rule of law operations must be totally integrated into all phases and aspects of military operations and the unit mission;

- US Army rule of law efforts must be completely coordinated and synchronized with other rule of law efforts, especially those of the host nation, and must recognize what role the military is organizationally qualified to fill; and

- Military rule of law operations must be effects-based.

Before addressing these lessons learned, it is important to highlight the discussion surrounding the definition of rule of law. There are divergent, and often conflicting, views among academics, US government agencies, US allies and even within the Department of Defense, on what is meant by the rule of law. ${ }^{5}$ This definitional ambiguity allows two organizations or individuals to be deeply committed to accomplishing rule of law tasks, yet proceed in diametrically opposed directions.

Additionally, it is important to discuss the obligation that international law creates to conduct rule of law operations. Recent court decisions such as those of the United Kingdom's House of Lords in Al-Jedda, ${ }^{6}$ the European Court of Human Rights cases from Kosovo ${ }^{7}$ and Canada's Amnesty International $v$. Canada ${ }^{8}$ have relied on Security Council resolutions to determine the substance and extent of legal obligations imposed on armed forces. The United Nations Security Council has signaled through several resolutions ${ }^{9}$ that supporting and promoting rule of law initiatives are not only permissible, but are obligations that participants in armed conflict are required to fulfill. It is incumbent on US forces to be aware of these emerging practices and recognize that these obligations will likely follow any armed conflict, whether brought on by reason of occupation or some other theory. With international law imposing additional obligations to carry out rule of law operations, it is more crucial than ever to catalogue lessons learned, analyze their application to doctrine and ensure that the US military is conducting its rule of law operations appropriately. 


\section{To Be Effective, Rule of Law Operations Must Be Totally Integrated into All Phases and Aspects of Military Operations and the Unit Mission}

In the aftermath of World War II, the US military embarked on a massive rule of law project that continued for years and involved a large pool of military resources. However, as the Cold War heated up, the focus transitioned from rebuilding a devastated Europe to defending a reconstructed Europe from attack. As a result, the focus of military doctrine, training, manning and equipping also adapted to this new environment. While this adaptation was necessary, it drew resources and expertise away from rule of law capabilities. Over the subsequent decades, resources, experience and training remained focused in other areas. The result was that JAs who deployed to Afghanistan felt as though they were working in an emerging area of doctrine without guidance or training. ${ }^{10}$

This was felt not only by JAs, but by the Army as a whole. The lack of doctrine and guidance was a significant lesson learned from early operations and sparked a number of initiatives and actions that have tried to remedy this doctrinal and training gap. These efforts have included a somewhat circular process of (1) analyzing lessons learned from military operations, (2) rewriting doctrine to include principles drawn from these lessons, (3) including this doctrine in mission training and mission rehearsal exercises at combat training centers and then (4) collecting lessons learned from the application of new doctrine in actual military operations which can then be reviewed and fed back into the doctrine review process.

The first step in this process-analysis-led to the recognition that rule of law efforts needed to be reintegrated into Army doctrine. The second step, rewriting doctrine to reflect this recognition, is well illustrated by several publications that emerged after the initial stages of engagement in Iraq and Afghanistan. The most recent Joint Publication 3-0, Doctrine for Joint Operations, divides military operations into three categories: offensive operations, defensive operations and stability operations. ${ }^{11}$ Promoting stability operations to the same level as offense and defense is a dramatic change from a Cold War paradigm where defending the Fulda Gap against an invasion by Warsaw Pact forces was the primary focus.

The importance of stability operations is echoed in the 2005 Department of Defense Directive 3000.05, Military Support for Stability, Security, Transition, and Reconstruction (SSTR) Operations, which states:

Stability operations are a core U.S. military mission that the Department of Defense shall be prepared to conduct and support. They shall be given priority comparable to combat operations and be explicitly addressed and integrated across all [Department 


\section{Afghanistan Legal Lessons Learned: Army Rule of Law Operations}

of Defense] activities including doctrine, organization, training, education, exercises, materiel, leadership, personnel, facilities, and planning. ${ }^{12}$

Rule of law operations are an essential subset of stability operations. Declaring stability operations to be a core US military mission has driven an increase in the expenditure of training resources and has changed the planning and execution stages to ensure units can accomplish rule of law missions.

Doctrine has also been rewritten to reflect the roles the military should be prepared to fulfill to further the rule of law. One change in doctrine acknowledges that the military may be called upon to play a supporting governance role. Joint Publication 3-0 discusses the various phases of an operation, the last two of which are "stabilize" and "enable civil authority." To complete these last two phases, "[t]he joint force may be required to perform limited local governance, integrating the efforts of other supporting/contributing multinational, [other government agencies, international government agencies, or nongovernmental agencies (NGOs)], participants until legitimate local entities are functioning. This includes providing or assisting in the provision of basic services to the population." 13 Further, "The joint force will be in a supporting role to the legitimate civil authority in the region throughout the 'enable civil authority' phase." 14

Current doctrine also recognizes that the military can aid rule of law development by creating security, a prerequisite for the rule of law, and a fundamental military mission throughout all phases of an operation. Depending on the circumstances, "it may be the only real contribution that US forces can make towards implementing the rule of law." ${ }^{15}$ Experience has taught that, for a multitude of reasons, there is a direct correlation between the establishment of a safe and secure environment and the ability to accomplish rule of law objectives. Achieving such an environment requires in-depth planning from the very earliest stages of the operation.

Finally, military doctrine has changed to recognize that US forces promote the rule of law when their own actions, across the spectrum of military operations, reinforce the legitimacy of the rule of law even before a stable environment has been created. The Rule of Law Handbook accurately states that "[a] command's ability to establish the rule of law within its area of control is dependent in large part on its own compliance with legal rules restricting soldiers' (and the command's own) discretion." ${ }^{16}$ This idea is echoed in the Center for Army Lessons Learned compilation on counterinsurgency (COIN) operations which states that " $[\mathrm{m}]$ ilitary actions [must be] conducted in consonance with specified civil rights, liberties, and objectives." 17 The only way to do that is to ensure that rule of law considerations are an essential part of the unit mission and intertwined with all military operations and 
training. Every soldier, sailor, airman and Marine must recognize that his or her actions can have a profound effect on the success of the national strategic interest in supporting rule of law operations throughout the world.

To effectively carry out these and other doctrinal changes, the Army has transformed its combat training centers into stability operations training grounds. The National Training Center in California, Joint Readiness Training Center in Louisiana and Joint Multinational Readiness Center in Germany have all incorporated stability operations, including rule of law operations, into their training scenarios. Units routinely conduct "mission rehearsal exercises" at these locations to prepare themselves for the actual events that will take place in an impending deployment to Afghanistan or Iraq. This training not only incorporates the new stability operations doctrine, but also the most recent lessons learned from units currently deployed. With this training, units are better prepared to deploy to Afghanistan and similar environments and support rule of law operations.

The importance of promoting and complying with the rule of law has been clearly stated in almost every "lesson learned" from deployed units. The doctrine is now in place and in the process of continual review based on continuing feedback from current military operations. Furthermore, mechanisms for implementing the doctrine, such as training at the combat maneuver training centers, are also in place. What remains is for the doctrine to be implemented on the ground, ensuring that these legal lessons are truly learned, not lost.

\section{US Army Rule of Law Efforts Must Be Completely Coordinated and Synchronized with Other Rule of Law Efforts, Especially Those of the Host Nation, and Must Recognize What Role the Military Is Organizationally Qualified to Fill}

Because rule of law efforts are so complex, they are most effective when all contributing groups, especially the host nation, coordinate with one another rather than inadvertently working at cross purposes. The Rule of Law Handbook illustrates this point:

Rule of law operations in Iraq and Afghanistan have repeatedly demonstrated that rule of law practitioners who seek to coordinate efforts, funding, and resources with other agencies and organizations yield the most effective results.... [A]s hostilities come to a close other [US Government] agencies ... will arrive in theater. Regional, state-based economic and security organizations such as the Gulf Cooperative Council or the Organization for Security and Cooperation in Europe ... may have a presence. The United Nations may, depending upon the operation have a presence, as may nongovernmental agencies with an interest in human rights and justice. Each of these 


\section{Afghanistan Legal Lessons Learned: Army Rule of Law Operations}

organizations is a tool and potential force multiplier for the rule of law Judge Advocate to maximize the effect of his efforts. ${ }^{18}$

Unfortunately, the US military and the world at large had not yet learned this lesson when operations began in Afghanistan:

Pursuant to the Bonn Agreement, the rule of law effort in Afghanistan was organized by a "lead nation" approach, with different countries taking the lead in developing different aspects of the rule of law in Afghanistan. Germany became the lead nation for developing the Afghan police force, while Italy was given responsibility for developing the judicial sector .... The split international effort has proven unwieldy for many reasons, since a rule of law effort has to address police and judicial reform in concert.... [and] the division of tasks among nations did not necessarily match the structure of the Afghan government's legal administrative apparatus. ${ }^{19}$

Not only is the lead-nation approach unwieldy, it has not been well received by Afghanistan. The 2008 Paris Conference made it clear that Afghanistan is the lead nation for Afghanistan's rule of law initiatives. This led to a change in approach by interested nations and caused some adaptation to the lead-nation concept. ${ }^{20}$

This incongruent approach on the international level was little different from the approach at the US national level. US agencies involved in rule of law operations in Afghanistan include the Department of State, the Office of the Coordinator for Reconstruction and Stabilization (S/CRS), the Bureau for International Narcotics and Law Enforcement Affairs, the United States Agency for International Development (USAID), the Department of Justice, the United States Institute for Peace, the Department of Defense (including judge advocates, civil affairs personnel, military police and Provincial Reconstruction Teams), ${ }^{21}$ the Defense Institute of International Legal Studies and the Combined Security Transition Command-Afghanistan. One lesson learned that has been constant throughout the operation in Afghanistan, and has been emphasized as recently as the fall of 2007 , is that all these organizations are working hard, but their efforts are not well coordinated.

This lack of concerted effort on rule of law operations was noted early in Afghanistan operations and the US government has taken steps to try and solve this problem. As previously mentioned, the Department of Defense promulgated Joint Publication 3-0 and Department of Defense Directive 3000.05, both of which draw attention to the necessity of interagency and intergovernmental cooperation for long-term success. ${ }^{22}$ In December of 2005, President Bush promulgated National Security Presidential Directive 44, which recognizes the prior lack of coordination and states: 
To achieve maximum effect, a focal point is needed (i) to coordinate and strengthen efforts of the United States Government to prepare, plan for, and conduct reconstruction and stabilization assistance and related activities in a range of situations that require the response capabilities of multiple United States Government entities and (ii) to harmonize such efforts with U.S. military plans and operations. ${ }^{23}$

The directive then identifies who will be responsible for this coordination, stating:

The Secretary of State shall coordinate and lead integrated United States Government efforts, involving all U.S. Departments and Agencies with relevant capabilities, to prepare, plan for, and conduct stabilization and reconstruction activities. The Secretary of State shall coordinate such efforts with the Secretary of Defense to ensure harmonization with any planned or ongoing U.S. military operations across the spectrum of conflict. ${ }^{24}$

This directive was followed by the creation of the Department of State, Office of the Coordinator for Reconstruction and Stabilization in August 2004. The mission of the S/CRS is " $t$ ] o lead, coordinate and institutionalize U.S. Government civilian capacity to prevent or prepare for post-conflict situations, and to help stabilize and reconstruct societies in transition from conflict or civil strife, so they can reach a sustainable path toward peace, democracy and a market economy." 25

The S/CRS acknowledges the difficulty in harmonizing efforts in this area. Its website proclaims:

Until now, the international community has undertaken stabilization and reconstruction operations in an ad hoc fashion, recreating the tools and relationships each time a crisis arises. If we are going to ensure that countries are set on a sustainable path towards peace, democracy and a market economy, we need new, institutionalized foreign policy tools - tools that can influence the choices countries and people make about the nature of their economies, their political systems, their security, indeed, in some cases about the very social fabric of a nation. ${ }^{26}$

Unfortunately, neither the establishment of the S/CRS nor any other initiative by the Department of Defense, Department of State or any other agency has been sufficient to create a synchronized approach to rule of law in Afghanistan, even after almost seven years of rule of law operations.

It would be unfair to attribute this failure either to the Department of State or to the Department of Defense, or to any other single factor for that matter. But there are clearly some lessons that have been learned by the US Army. The first is that any successful rule of law initiative must be host-nation driven. If the people and governments (whether local, regional or national) of Afghanistan are not consulted, or 


\section{Afghanistan Legal Lessons Learned: Army Rule of Law Operations}

fail to embrace proposed rule of law operations, not only are the operations doomed to failure, they will not promote the strategic interests of the United States. Conversely, when Afghanis and the Afghan government are a part of a cooperative effort, great progress can be made. One such example of a successful rule of law collaboration with the host nation is the creation of the Provincial Justice Conferences (PJC) program in Afghanistan:

The Provincial Justice Conferences (PJCs) program attempts to [bring Government of Afghanistan (GoA)] justice officials from Kabul to meet their counterparts in the provinces to discuss the obstacles to delivery of justice services to the province and to identify solutions that can be instituted expediently and in a cost-effective way. Followup PJCs are generally scheduled within a period of three to six months to check on progress made on the identified solutions and to discuss outstanding issues. One essential key to a successful PJC has been the invitation and inclusion of all interested [US government (USG)] agencies, the international community, and NGO representatives. Each agency or organization has the benefit of significant, specialized, and diverse experience. With the inclusion of as many subject-matter experts as possible, new ideas may emerge to correct persistent problems.

As of the first quarter of 2007, PJCs and follow-up PJCs [had] been conducted in six provinces in Afghanistan. The first PJCs drew small attendance from among the provincial justice officials, but more recent PJCs have drawn upwards of 150 people from the national, provincial, and district levels, and, in some cases, from neighboring provinces. A typical PJC program consists of several distinct parts. First, all participants are taken on a tour of justice facilities in the provincial capital, to include the prison, police headquarters/detention centers, judges' office, prosecutor's office, courthouse, and defense counsel offices (if any). This feature gives participants a first-hand view of the justice infrastructure and an opportunity to observe justice officials in their own environments. Second, a general session of all participants is convened and hosted by the provincial governor. Brief comments from the governor, justice officials, and USG/ international participants are presented. After a communal lunch, hosted by one or more of the USG participants, conferees are divided into groups representing their individual justice interests - police, judges, prosecutors, defense counsel, and prison administrators. These groups discuss specialized problems and their potential solutions. The small groups take notes on their discussions from which a mark plan can be developed. Finally, the small group leaders from either GoA or the provincial government present summaries of their discussions to a final general session at the end of the day. ${ }^{27}$

Organizing a PJC is a difficult and time-consuming process and becomes more so as the organizing rule of law officer attempts to include all interested agencies. However, it is this type of coordination and inclusion that links agency resources with the Afghanis who are attempting to create the rule of law in courtrooms and 
police stations. This host-nation lead in rule of law programs is vital to their continued vitality and eventual success.

A second lesson is that the military is not the most qualified or appropriate body to conduct many aspects of rule of law operations. Department of Defense Directive 3000.05 recognizes this and states, "[m]any stability operations tasks are best performed by indigenous, foreign, or U.S. civilian professionals." ${ }^{28}$ There are simply tasks that the military is not the most qualified to perform. A recent after-action review highlights this point:

The military possesses an organizational culture that is different from the rest of the interagency. The military skill sets are required in order to establish the rule of law initially, and then other elements of national power are better suited to restore economic and industrial power. Two main points of understanding are (1) civilians are not in the military chain of command and do not accept military leadership and (2) civilians cannot be ordered to do anything. The interagency operates on the unity of effort, while the military prefers unity of command. ${ }^{29}$

Additionally, it would simply be counterproductive for the military to undertake certain tasks, as doing so could create reliance on military action by the host nation and others.

Despite the military's inherently limited ability to implement the rule of law, in the absence of other options, the military may find it necessary to step into a vacuum in order to ensure that certain necessary tasks are accomplished. Department of Defense Directive 3000.05 also recognizes this side of the coin and, after recognizing that many stability operations are ideally left to others, states that, "[n] onetheless, U.S. military forces shall be prepared to perform all tasks necessary to establish or maintain order when civilians cannot do so." ${ }^{30}$ While few would likely quibble with this statement, applying it is more difficult, especially determining when the time is right for the military to step up and perform these tasks as opposed to waiting for others. This difficult decision must be made and made competently by commanders and JAs on the ground using their best judgment.

A third lesson is that the rule of law is more effectively implemented when all players act in concert. JAs need to plan for and work within the multinational and interagency environment in order to maximize efficiency, effectiveness and engagement. If the US military doesn't function within the joint, interagency and multinational environment when forwarding rule of law initiatives, it simply does not function effectively. As the Rule of Law Handbook accurately states, "[w] hat is agreed upon by almost every individual who has worked in this area is that joint, inter-agency, and multinational coordination is the basic foundation upon which all rule of law efforts must be built." ${ }^{11}$ And further: 


\section{Afghanistan Legal Lessons Learned: Army Rule of Law Operations}

Without coordination with other players in the rule of law arena, the efforts of a single contributor in isolation are at best less than optimal and at worst counterproductive to the overall rule of law reform objectives being pursued. Quite simply, coordination and synchronization is to the rule of law effort what fires and maneuver is to the high intensity conflict. ${ }^{32}$

As the Army internalizes this, it will be better able to coordinate with other agencies.

Despite initial and continuing difficulties, there have been instances in which the military has worked successfully with other agencies to create positive results. The following illustration from the Rule of Law Handbook is based on lessons learned through after-action reviews. While lengthy, it demonstrates quite clearly the increased likelihood of success for rule of law operations when a broad range of parties are involved.

Nowhere was the interagency success more evident than the justice sector achievements in the Wardak province known as the Wardak Model Justice Project. In late 2005, the Justice Sector Support Program (JSSP), a contractor of the [Department of State (DOS)] International Narcotics and Law Enforcement Affairs Bureau (INL), began a training program for provincial and district level judges and prosecutors in Maydan Wardak. Almost simultaneously, but without advanced coordination, DOD rule of law and [Civil Affairs (CA)] personnel teamed up to build a justice administration building in Maydan Shar. Using [Commander's Emergency Response Program (CERP)] funds, available to tactical commanders for urgent and humanitarian rebuilding projects in post-conflict Afghanistan and Iraq, the [Combined Forces Command-Afghanistan (CFC-A)] rule of law and CA team obtained the blueprints for a generic administration building from USAID. USAID was using the blueprints to build up to 40 provincial courthouses throughout Afghanistan. Using these blueprints, CFC-A began construction in early 2006 on the justice administration building in Maydan Shar.

Momentum gathered as the people of Maydan Wardak generated more enthusiasm for the improvements being made. The USG agencies began to look more carefully at each other's rule of law activities in Maydan Wardak, and, aided by strong leadership on the Special Committee for the Rule of Law [,] began a concerted coordination effort to build on those successes. Lessons learned were shared among the Special Counselor on the Rule of Law agency representatives, resulting in more efficient delivery of proposed projects.

USAID began construction on a new courthouse, and one of its contractors offered to introduce its new paper-based court administration system in Maydan Shar. CFC-A also provided a justice motor-pool (with maintenance and fuel packages) and sponsored a public awareness campaign to let the citizens of the province know the 
steps being taken to improve the delivery of justice services. At the same time, CFC-A contracted with an Afghan NGO to provide defense counsel services to criminal defendants in Wardak and five other provinces. Ultimately, building on the combined efforts of the other USG agencies, the DOS announced in late 2006 that it would build a new, state-of-the-art prison and national corrections training facility in Maydan Wardak. The result of the ongoing combined efforts of these agencies was the Wardak Model Justice Project, the name reflecting the goal of the agencies involved that the justice system in Maydan Wardak should be rebuilt to serve as a model for the international community and the GoA for such improvements in other provinces.

Interagency cooperation and communications between the agencies involved in Wardak continues in 2007. A group of agency representatives and provincial justice and government officials gathers monthly in Wardak to discuss problems with and future plans for further expansion of the Wardak Model Justice Project. Visibility on this project remains high as the provincial governor continues to chair each monthly meeting. Participants from all USG agencies are invited to these meetings, as well as representatives of the international community and various NGOs. The recently arrived Turkish Provincial Reconstruction Team (PRT) brought a police training team with them, and this program has been incorporated into the Wardak Model Justice Project. Similar efforts are being planned for Nangarhar, Bamyian, and Logar provinces as part of [a] wider DOS strategic plan for implementation of its rule of law program. $^{33}$

While the Wardak Project clearly illustrates the benefits that can be achieved when several agencies each work toward a common end, much of the success achieved in Wardak was more a product of coincidence than of premeditated coordination on the part of the agencies involved. In the vast majority of cases, conscientious, institutionalized coordination will be needed, as illustrated by the following example:

In early 2006, a Special Counselor on the Rule of Law was appointed by the DOS to coordinate interagency rule of law efforts in Afghanistan, to assure that gaps and overlaps in such efforts were corrected, and to assist in the development of a broader USG rule of law agenda. ... A committee of representatives from each USG agency involved in rule of law activities was organized and was chaired by the Special Counselor who was later replaced by a senior lawyer who currently holds the title of Rule of Law Coordinator.... Regular and frequent rule of law meetings have resulted in much greater coordination of rule of law efforts at the strategic level, the development of strong interpersonal and cooperative relationships, and a greater awareness of each agency's rule of law activities among and between all participants and the rule of law [sic] Coordinator. ${ }^{34}$ 


\section{Afghanistan Legal Lessons Learned: Army Rule of Law Operations}

If the Provincial Justice Conferences program, the creation of the office of Rule of Law Coordinator and the Wardak Project are indicative of the future of interagency and international coordination, there is much to be optimistic about concerning rule of law operations in Afghanistan. The clear lesson learned is that it is only through complete coordination and inclusion of host-nation components that all the disparate efforts to promote rule of law within Afghanistan can be successful.

\section{To Be Effective, Military Rule of Law Operations Must Be Effects-Based}

In October 2002 after a year of operations in Afghanistan, Desmond SaundersNewton and Aaron B. Frank wrote in a National Defense University publication that

[t] he U.S. military, under the guidance of the Secretary of Defense, is moving toward a new concept of military planning and operations that is agile and adaptable to the conflict at hand.... The new concept called effects-based operations encompasses processes, tools, and organizations that focus planning, executing, and assessing military activities for the effects produced rather than merely tallying the number of targets destroyed. ${ }^{35}$

The authors go on to write that what is needed is not a "traditional force-onforce analysis," but "the skillful use of force in conjunction with diplomatic, economic, legal, and other instruments of national power" 36 that are characteristic of effects-based operations.

This effects-based approach has been used effectively in Afghanistan, particularly in rule of law initiatives. ${ }^{37}$ Because effects-based operations are "fundamentally about linking end states and objectives to tactical tasks through identifying and producing desired effects to accomplish missions," ${ }^{38}$ it is vital for JAs to focus on the effect desired, rather than on the project that may or may not accomplish this effect. This is reflected in the Rule of Law Handbook, which states:

[I]nstitutional improvements can be valuable, but rule of law projects should ultimately focus on bringing about particular effects, not on the institutions that may exist following the completion of the project. Thus, it is critical to keep in mind what values are represented by the rule of law so that those values, not some intermediate, institutionally focused objectives, drive the rule of law efforts. ${ }^{39}$

To illustrate this point, consider the administrative functioning of a court system. In many areas of Afghanistan, the court system had no administrative 
structure, such as a docketing and case-tracking system, or method of reporting and documenting case decisions. As JAs recognize the need to institutionalize case administration, they may be tempted to try and recreate a modern court system, complete with computerized databases and transfer and recording capabilities. However, one of the lessons learned from such efforts in Afghanistan is that "it is usually better to favor low-tech solutions, such as manual court reporting and paper filing systems." ${ }^{40}$ More modern systems require trained computer personnel to operate and maintain the systems. Even more basic, such systems require continuous access to electricity. While these aspects of running a court system may not be issues in the United States, they are significant constraints in Afghanistan and other similar situations where the US Army operates. Such considerations cause the Rule of Law Handbook to conclude, "[w]hen it comes to administrative infrastructure, the clear lesson is that simplicity is key." ${ }^{41}$

The lesson here is that a JA who is not focused on effects may instead focus on creating the best administrative court system possible, using the most modern technologies. However, if the effect desired is a functioning administrative court system that can effectively maintain itself, a concentration on low-tech solutions is much more likely to succeed.

While this is a simplistic example, a similar analysis can be applied to rule of law operations generally. Important initiatives, such as establishing a defense bar, ensuring a trained and independent judiciary, establishing judicial oversight on police activities and maintaining a penal system that complies with fundamental human rights, all benefit from an effects-based approach.

A comprehensive and effective effects-based approach to rule of law operations has several components; the first is the completion of an initial assessment. Such assessments look at the current and prior situations and develop a factual foundation upon which future actions can occur. These assessments are often done in the US Army by civil affairs personnel, but every "Judge Advocate engaged in the rule of law mission must become comfortable with creating and reviewing assessments of foreign nations' legal systems, including courts, private organizations, police, and prisons." ${ }^{22}$ Such assessments should include the history and tradition of the local legal system, identification of which persons and organizations have a role in the system, and what capabilities and needs currently exist. ${ }^{43} \mathrm{~A}$ good assessment that is continually updated will provide the foundation for rule of law operations that can focus on and accomplish the desired rule of law effects.

A second component, and one of the most difficult aspects of effect-based operations, is determining measures of effectiveness that will accurately reflect whether the desired effects have been achieved. Metrics, which are quantitative or qualitative systems of measurement, have become an important part of assessing rule of 


\title{
Afghanistan Legal Lessons Learned: Army Rule of Law Operations
}

law effectiveness. "Meaningful metrics permit the Judge Advocate ... to not only measure whether the mission is accomplishing its goals, but to also convey information to superiors and policy makers in a quantifiable manner that is not purely anecdotal." ${ }^{44}$ An example of a meaningful metric measuring overall movement toward the rule of law would incorporate individuals' perceptions of whether (or to what degree) the law is superior to individuals, is applied by an impartial and independent body and is applied consistently to all subjects.

In attempting to develop metrics that measure success, it is tempting to revert to focusing on means rather than effects. The Rule of Law Handbook reminds us why this urge must be overcome:

\begin{abstract}
At the sustained deployment stage, merely focusing upon the number of court houses operating, the number of prison cells available, and the number of judges hearing a given number of cases begins to tell an increasingly irrelevant story. Now operations are moving into the higher realm of what constitutes establishment of the rule of law. A tyrannical system despised by its population can have courthouses, cells, and case adjudication statistics and yet the rule of law does not exist. Once a plateau of recovery is reached where the facilities and personnel exist to operate the legal system, then the metrics upon which assessments and planning are built must shift to analyzing the efficacy and legitimacy of the system. ${ }^{45}$
\end{abstract}

The veracity of the effects-based approach is echoed in a recent publication from the Center for Army Lessons Learned. Michael McCoy writes that Provincial Reconstruction Teams

should design measures of effectiveness that delineate the perception of safety, the reduction of security incidences that impact daily life, the capacity of the government to provide basic services and rule of law, and the popular acceptance of legitimate formal and informal organizations and leaders by both the majority of the population and disaffected elements of the population. ${ }^{46}$

Designing metrics that adequately measure the desired effects and provide useful input into the way forward is a difficult task. It is easy to see why Samuel Young, writing concerning V Corps operations, concludes that " $[t]$ he complexity of conducting non-lethal Effects Based Operations in a Joint, Interagency, Intergovernmental, and Multinational (JIM) environment challenges the mindset, training, and organization of our warfighting formations." ${ }^{47}$

Despite some difficulties, this effects-based approach has been utilized with great success in Afghanistan by members of the 10th Mountain Division whose experiences were recorded in a recent Initial Impressions Report. Prior to deployment, the division developed a comprehensive effects-based plan to guide it during its year in 
Afghanistan. Its objectives were to improve security; support the local, provincial and national governments; and improve local and provincial infrastructure.

Beginning with their campaign plan, operational desired effects were identified as "results/conditions" that[,] when achieved, represent accomplishing stated objectives. Desired effects were clearly articulated for each operational objective that in turn served as guides for developing tactical missions and tasks for subordinate units. Throughout all planning and coordination activities, the staff was disciplined to review stated effects in the campaign plan and then develop activities and tasks to help generate the stated desired effects.

The Division's operations were assessment driven. Daily, weekly, and monthly assessments of the progress of operations helped determine what [Combined Joint Task Force]-76 was doing right and what areas of the plan needed adjustment. These assessments were focused on both measures of performance of tasks and measures of effectiveness in achieving desired effects. ${ }^{48}$

The Initial Impressions Report concludes by stating that " $\mathrm{t}]$ he Division is very comfortable with using an effects-based approach to guide operations" and " $t \mathrm{t}] \mathrm{he}$ 10th [Mountain] was clearly very successful during their year in Afghanistan." 49

Though reformulating efforts to focus on effects and finding meaningful metrics to measure these effects may be difficult, it is clear that the effects-based approach to rule of law operations is the most effective. The lesson learned for JAs is that they must adopt and internalize the effects-based approach and become fully engaged in the metrics process of assessment and analysis.

\section{Conclusion}

As is aptly illustrated by the Naval War College's dedication of a complete workshop and volume of the "Blue Book" to this topic, there are numerous lessons to be learned from the current military operations in Afghanistan. For the US Army, some of the most significant legal lessons have been in the area of rule of law operations. The Army is still in the process of learning many of these lessons, but some have already been put into practice, benefitting operations in Iraq. As we continue to apply what we have learned by integrating the rule of law into military practice, cooperating with other agencies and measuring the success of our operations by their effects, future rule of law efforts will better serve the US strategic national interest. 


\section{Afghanistan Legal Lessons Learned: Army Rule of Law Operations}

\section{Notes}

1. The White House, National Security Strategy of the United States 3, 9-10, 17, 19, 22, 28 (Sept. 2002), available at http://www.acq.osd.mil/ncbdp/nm/docs/Relevant\%20Docs/national _security_strategy.pdf.

2. National Security Presidential Directive/NSPD-44 (2005), available at http://www.fas.org/ irp/offdocs/nspd/nspd-44.html.

3. Center for Army Lessons Learned, Division Commanders Guide to Information Operation in OIF \& OEF Handbook (Dec. 2007), available at https://callsearch.leavenworth.army.mil/ CALL2Search/isysquery/9e25b547-35fc-469d-8aaf-84ad401c78c1/19/doc/ (available to current DoD employees and their contractors through approved website access).

4. Center for LAW and Military Operations, THE Judge AdVOCATE General's LEGAL CENTER SCHOOL AND JOINT FORCE JUDGE ADVOCATE, UNITED STATES JOINT FORCES COMMAND, RULE OF LAW HANDBOOK: A PRACTITIONER'S GUIDE FOR JUDGE ADVOCATES i (2007) [hereinafter RULE OF LAW HANDBOOK].

5. Id. The UN Security Council's definition is a good starting point and comports with most definitions of the rule of law: (1) The law is supreme, (2) the law is applied by an independent institution (such as a judicial branch) and (3) the law applies equally to all subjects of the law. See FEDERAL MINISTRY FOR EUROPEAN AND INTERNATIONAL AFFAIRS (AUSTRIA) \& INSTITUTE FOR INTERNATIONAL LAW AND JUSTICE, NEW YORK UNIVERSITY SCHOOL OF LAW, THE U.N. SECURITY COUNCIL AND THE RULE OF LAW: THE ROLE OF THE SECURITY COUNCIL IN STRENGTHENING A RULES-BASED INTERNATIONAL SYSTEM 3-4 (2008).

6. R (Al-Jedda) v. Secretary of State for Defence, [2007] UKHL 58 (House of Lords 2007).

7. Behrami v. France and Saramati v. France, Germany and Norway, apps. nos. 71412/01 and 78166/01, 45 Eur. Ct. H.R. 41 (2007) (Grand Chamber).

8. Amnesty International Canada v. Canada (Attorney General), 2008 FC 336 (2008).

9. S.C. Res. 1806, U.N. Doc. S/RES/1806 (Mar. 20, 2008); S.C. Res. 1662, U.N. Doc. S/RES/ 1662 (Mar. 23, 2006); S.C. Res. 1746, U.N. Doc. S/RES/1746 (Mar. 23, 2007); S.C. Res. 1802, U.N. Doc. S/RES/1802 (Feb. 25, 2008).

10. Rule of Law Handbook, supra note 4, at i.

11. Chairman of the Joint Chiefs of Staff, Joint Publication 3-0, Doctrine for Joint Operations, at V-1 (Sept. 2006, with change 1, Feb. 13, 2008), available at http://www.dtic.mil/doctrine/ jel/new_pubs/jp3_0.pdf [hereinafter Joint Pub. 3-0].

12. Department of Defense, Directive 3000.05, Military Support for Stability, Security, Transition, and Reconstruction (SSTR) Operations para. 4.1 (Nov. 28, 2005), available at http:// www.dtic.mil/whs/directives/corres/pdf/300005p.pdf [hereinafter DoD Directive 3000.05]. See also Joint Pub. 3-0, supra note 11, at V-1, which defines stability operations as "missions, tasks, and activities [that] seek to maintain or reestablish a safe and secure environment and provide essential governmental services, emergency infrastructure reconstruction, or humanitarian relief."

13. Joint Pub. 3-0, supra note 11, at IV-29.

14. Id. at IV-30.

15. Rule of Law Handbook, supra note 4 , at 8.

16. Id. at 16

17. Center for Army Lessons Learned, Southern Afghanistan COIN Operations 24 (2006), available at https://callsearch.leavenworth.army.mil/CALL2Search/isysquery/9e25b547-35fc $-469 \mathrm{~d}-8 \mathrm{aaf}-84 \mathrm{ad} 401 \mathrm{c} 78 \mathrm{cl} / 35 / \mathrm{doc}$ ( (available to current DoD employees and their contractors through approved website access). 
18. RULE OF LAW HANDBOOK, supra note 4 , at 112.

19. Id. at 51 (footnote omitted).

20. M. Ashraf Haidari, Paris Conference: Aid Effectiveness Key to Addressing Afghanistan's Rebuilding Challenges (June 12, 2008), EURASIANET, http://www.eurasianet.org/departments/ insight/articles/eav061208f.shtml.

21. One of the three focuses of Provincial Reconstruction Teams is to "[i]ncrease provincial stability through international military presence and assist in developing nascent host nation security and rule of law capacity." Michael McCoy, Center for Army Lessons Learned, Provincial Reconstruction Team Playbook (Sept. 2007), available at https://callsearch leavenworth.army.mil/CALL2Search/isysquery/9e25b547-35fc-469d-8aaf-84ad401c78c1/13/doc/ (available to current DoD employees and their contractors through approved website access) [hereinafter PRT Handbook].

22. For example, DoD Directive 3000.05, supra note 12, para. 4.4 states:

Integrated civilian and military efforts are key to successful stability operations. Whether conducting or supporting stability operations, the Department of Defense shall be prepared to work closely with relevant U.S. Departments and Agencies, foreign governments and security forces, global and regional international organizations, U.S. and foreign non-governmental organizations, and private sector individuals and forprofit companies.

23. National Security Presidential Directive/NSPD-44, supra note 2, para. 3.

24. Id., para. 4.

25. US Department of State, Office of the Coordinator for Reconstruction and Stabilization, http://www.state.gov/s/crs/ (last visited Feb. 18, 2008).

26. US Department of State, About S/CRS, http://www.state.gov/s/crs/c12936.htm (last visited Feb. 18, 2009).

27. RULE OF LAW HANDBOOK, supra note 4 , at 56 (footnote omitted).

28. DoD Directive 3000.05 , supra note 12 , para. 4.3.

29. Center for Army Lessons Learned, Leader Challenges - OEF and OIF (Dec. 2005), available at https://callsearch.leavenworth.army.mil/CALL2Search/isysquery/9e25b547-35fc-469d-8aaf $-84 \mathrm{ad} 401 \mathrm{c} 78 \mathrm{c1} / 33 / \mathrm{doc}$ ( available to current DoD employees and their contractors through approved website access).

30. DoD Directive 3000.05 , supra note 12 , para. 4.3 .

31. RULE OF LAW HANDBOOK, supra note 4 , at ii.

32. Id.

33. Id. at 54-55 (footnote omitted).

34. Id. at 52-53 (footnote omitted).

35. Desmond Saunders-Newton \& Aaron B. Frank, Effects-Based Operations: Building the Analytic Tools, DEFENSE HORIZONS, Oct. 2002, at 1, http://www.ndu.edu/inss/DefHor/DH19/ 193-619_DH19.pdf.

36. Id. at 2 .

37. Center for Army Lessons Learned, A Special Study on Effects-Based Approach to Military Operations (May 2005), available at https://callsearch.leavenworth.army.mil/ CALL2Search/ isysquery/263df3d8-ca0e-41c9-9d43-0ef4907e39bc/23/doc/ (available to current DoD employees and their contractors through approved website access).

38. Id.

39. RULE OF LAW HANDBOOK, supra note 4, at 19 (footnote omitted).

40. Id. at 75 .

41. Id. 


\section{Afghanistan Legal Lessons Learned: Army Rule of Law Operations}

42. Id. at 121 .

43. Id. at $121-34$.

44. Id. at 134 .

45. Id. at 137 .

46. PRT Handbook, supra note 21.

47. Samuel R. Young, Center for Army Lessons Learned, V Corps as Multi-National CorpsIraq (June 2007), available at https://callsearch.leavenworth.army.mil/CALL2Search/isysquery/ 263df3d8-ca0e-41c9-9d43-0ef4907e39bc/18/doc/ (available to current DoD employees and their contractors through approved website access).

48. Mike Stark, Initial Impressions Report (IIR) - 10th Mountain Division - Observations of a Modular Force Division Operating as a CJTF in OEF, 1.3 (2007), available at https:// callsearch.leavenworth.army.mil/call2-search/isysquery/556986ea-00d2-4eb4-a5b6 $-4 \mathrm{c} 739 \mathrm{a} 45695 \mathrm{~d} / 1 / \mathrm{doc}$ ( available to current DoD employees and their contractors through approved website access).

49. Id. 